Journal of Medicine (2017), 2(2): 86-93

https://doi.org/10.26911/theijmed.2017.02.02.02

\title{
Effect of Antihipoglycemic Sechium edule Jacq. Swartz. Etanol Extract on Histopathologic Changes in Hyperglycemic Mus musculus $\mathrm{L}$.
}

\author{
Jekson Martiar Siahaan \\ Department of Physiology, Faculty of Medicine, Methodist Indonesia University, Medan
}

\begin{abstract}
Background: Streptozotocin as diabetogenic can damage the pancreatic $\beta$ cells of animals tried through the oxidative stress process to increase blood sugar levels. Giving ethanolic extract of squash fruit has hypoglycemia effect because it contains flavonoids that act as antioxidants and antihiperglichemia. This study aimed is analyze the effect of ethanol extract of squash fruit to decrease blood sugar level and the change of pancreatic $\beta$ cell diameter.

Subjects and Method: This study was an experimental study with post-randomized controlled group design, using male white mice (Mus musculus L.) DD Webster strains randomized into 4 groups: negative control group, positive control group, group with extract ethanol of $100 \mathrm{mg} /$ $\mathrm{kgBB}$, and a group of ethanol extract of $200 \mathrm{mg} / \mathrm{kgBW}$ of pumpkin.

Results: The results showed a significant reduction in blood sugar levels if compared with the control group. The presence of changes in $\beta$ pankreas cell diameter on ethanol extract of $100 \mathrm{mg} /$ $\mathrm{kgBB}$ and $200 \mathrm{mg} / \mathrm{kgBB}$.

Conclusion: The conclusion of this study is the extract of ethanol fruit of $200 \mathrm{mg} / \mathrm{kgBB}$ squash significantly reduce blood sugar level of mice, the change of $\beta$ pankreas cell diameter on ethanol extract of 100mg/ kgBB and 200mg/ kgBB.
\end{abstract}

Keywords: streptozotocin, antihipoglikemia, flavonoid

Correspondence:

Jekson Martiar Siahaan. Physiology Teaching Staff ofMedicine Faculty, Methodist University of Indonesia Medan, Jl. Setia Budi Pasar 2, Medan 20132, Indonesia.

\section{BACKGROUND}

Streptozotocin (STZ) has a chemical name 2-Deoxy-2[[(methylnitrosoamino)carbonyl]amino]D-glucopyranose, obtained from Streptomyces achromogenes and structurally derived from nitrosourea (Akbarzadeh et al., 2007; Nugroho, 2006; Srinivasan and Ramarao, 2007). STZ has antineoplasmic, antibiotic and diabeto-genetic effects (Raza and John, 2012; Akbarzadeh, et al., 2007; Srinivasan and Ramarao, 2007). Its use as a diabetogenic was first performed by Rakieten in dogs and mice in 1963. STZ evokes free radicals that play a role in destroying pancreatic $\beta$ cells. The STZ mechanism is mediated primarily by $\mathrm{NO}$ formation and reactive oxygen generation. Superoxide anion reactive oxygen for- mation and increased activity of xanthine oxidase caused by STZ in mitochondria. STZ inhibits the krebs cycle and decreases mitochondrial oxygen consumption. The limited production of mitochondrial ATP subsequently results in a drastically reducing nucleotide of pancreatic $\beta$ cells. Increased ATP defo- phyzation will spur substrate increases for the enzyme xanthine oxidase (pancreatic $\beta$ cells have high activity on this enzyme), and further increase uric acid production. Xanthine oxidase will catalyze the formation of an active superoxide anion formation. Based on the superoxide anion formation process, hydrogen peroxide and superoxide radicals are formed. NO and reactive oxygen are the 
main causes of pancreatic $\beta$ cell damage (Srinivasan and Ramarao, 2007).

Persistent hyperglycemia in people with Diabetes Mellitus (DM) will lead to increased oxidative stress due to an imbalance between free radicals and natural antioxidants formed by the body. Increased oxidative stress can occur in Type 1 DM and Type 2 DM. Type 1 DM and oxidative stress will damage pancreatic $\beta$ cells while Type 2 DM will cause disruption of insulin production, release, and insulin function (Sheikhpour et al., 2013).

Oxidative stress in pancreatic $\beta$ cells destroys proteins, enzymes, lipid membranes, DNA and reduces immune and antioxidant responses, increases levels of lipid peroxidase and proinflammatory cytokines (Moussa, 2008). Chronic hyperglycemia can damage tissues including pancreatic islet cells. Various biochemical mechanisms due to glucose toxicity causing oxidative stress can be through 6 mechanisms namely methylglioxal and glycerin nonenzymatic proteins, polyol sorbitol pathways (aldose reductase), activation of hexosamine metabolism, activation of protein $\mathrm{c}$ kinase, and oxidative phosphorylation and glucose autotoxidation (Setiawan and Eko, 2005; Robertson, 2004; Sheikhpour, 2013; Shradha, 2010; Atalay, 2002).

Flavonoids including phenolic compounds, secondary metabolites produced by green plants except algae, can be found in cereals, vegetables and fruits. Flavonoids commonly found are flavones and flavones with $\mathrm{C}$ - and $\mathrm{O}$-glycosides, Cand $\mathrm{O}$-glycoside isoflavones, $\mathrm{C}$ - and $\mathrm{O}$ glycoside flavanones, C- and O-glycosides, and dihydrochloric, proanthocyanidin and anthocyanin, auron $\mathrm{O}$ glycosides, and dihydroflavoneol O-glycosides while the main flavonoids are flavans, flavanones, flavones, flavonols, flavanols, flavanonols, cetechins, anthocyanidins and isoflavones (Brahmachari, 2011; Rohyami, 2008; Redha, 2010).

Flavonoids are antidiabetic compounds by blocking glucose uptake in the intestines, improving glucose tolerance, disturbing carbohydrate metabolism through inhibition of enzyme a amylase and enzyme a glucosidase, stimulating glucose uptake by peripheral tissue. In addition, flavonoids also stimulate insulin production (insulin secretagogues) and act like insulin stimulating glycogen synthesis (insulin mimetics) (Brahmachari, 2011; Piparo, 2008; Getha et al., 2010). Flavonoids can repair damaged pancreatic tissue due to DNA alkylation by STZ so that insulin secretion increases and blood glucose levels go down (Suryani et al., 2013).

The oxidative stress caused by streptozotocin is a major cause of damage from pancreatic $\beta$ cells (Srinivasan and Ramarao, 2007). The pancreatic histopathologic changes may be a decrease in the number and diameter of pancreatic $\beta$ cells (Suarsana et al., 2010; Erwin et al., 2012; Ridwan et al., 2012). A decrease in the number of pancreatic $\beta$ cells in hyperglycemic animals began to appear on day 7 and continued to decline until day 28 . Increasing the number of pancreatic $\beta$ cells is caused by the body's own healing mechanisms through the improvement of $\beta$ cells and new cell divisions (mitosis) that occur gradually (Erwin et al., 2012). A decrease in the number of pancreatic $\beta$ cells results in pancreatic $\beta$-cell diameter, normal $\beta$ pancreatic $\beta$-cell diameter 100$400 \mu \mathrm{m}$ (Ridwan et al., 2012).

\section{SUBJECTS AND METHOD}

This study was a design experimental study of post test randomized controlled group design. The sample was male white mouse 
(Mus musculus L.) DD Webster strain was obtained by simple random sampling method. The samples were randomized into 4 groups: negative control group, positive control group (STZ $60 \mathrm{mg} / \mathrm{kgBB}$ ), group receiving STZ $60 \mathrm{mg} / \mathrm{kgBW}$ and ethanol extract of $100 \mathrm{mg} / \mathrm{kgBB}$, and STZ $60 \mathrm{mg} /$ $\mathrm{kgBB}$ and extract ethanol fruit chayote 200 $\mathrm{mg} / \mathrm{kgBB}$. Mice (Mus musculus L.) DD Webster DM strain if on the fourth day after STZ administration, blood sugar level $\geq 250 \mathrm{mg} / \mathrm{dl}$. When blood sugar levels had risen then the ethanol extract of the squash was given until the 28 th day.

\section{RESULTS}

The experimental animals used in this study were healthy trial animals with normal blood glucose (KGD). We performed KGD measurements using GlucoDr glucometer to make sure the animals tried normal.

Table 1. KGD before induction with STZ $60 \mathrm{mg} / \mathrm{kgBW}$

\begin{tabular}{|c|c|c|c|c|c|c|c|}
\hline \multicolumn{2}{|c|}{$\begin{array}{l}\text { P1 (Negative } \\
\text { Control) }\end{array}$} & \multicolumn{2}{|c|}{$\begin{array}{l}\text { P2 (Positive } \\
\text { Control) }\end{array}$} & \multicolumn{2}{|c|}{$\begin{array}{l}\text { P3 (Ethanol Extract of the } \\
\text { Squash } 100 \mathrm{mg} / \mathrm{kgBB} \text { ) }\end{array}$} & \multicolumn{2}{|c|}{$\begin{array}{l}\text { P4 (EthanolExtract of the } \\
\text { Squash } 200 \mathrm{mg} / \mathrm{kgBB} \text { ) }\end{array}$} \\
\hline U1 & 142 & U1 & 162 & U1 & 184 & U1 & 121 \\
\hline U2 & 138 & $\mathrm{U}_{2}$ & 148 & U2 & 152 & U2 & 197 \\
\hline U3 & 116 & $\mathrm{U}_{3}$ & 166 & $\mathrm{U}_{3}$ & 152 & $\mathrm{U}_{3}$ & 116 \\
\hline U4 & 154 & $\mathrm{U}_{4}$ & 175 & U4 & 188 & U4 & 176 \\
\hline U5 & 140 & U5 & 198 & $\mathrm{U}_{5}$ & 136 & U5 & 198 \\
\hline U6 & 130 & U6 & 184 & U6 & 162 & U6 & 184 \\
\hline $\mathbf{U}_{7}$ & 126 & $\mathrm{U}_{7}$ & 91 & $\mathrm{U}_{7}$ & 118 & $\mathrm{U}_{7}$ & 143 \\
\hline
\end{tabular}

Description: U1 (Repeat 1), U2 (Repeat 2) U3 (Repeat 3), U4 (Repeat 4), U5 (Repeat 5) U6 (Repeat 6), U7 (Repeat 7).

Based on the measurement of KGD white male mice before induced STZ (Table 1), white male mice did not have DM. KGD male white mouse called DM in this study was $\geq 250 \mathrm{mg} / \mathrm{dl}$. Studyers used STZ at a

dose of $60 \mathrm{mg} / \mathrm{kgBW}$, administered intraperitoneally (Park and Han, 2012) on day 4 of the KGD measurements shown in Table 2.

Table 2. KGD after induction with STZ $60 \mathrm{mg} / \mathrm{kgBW}$

\begin{tabular}{lcccc} 
Treatment & $\begin{array}{c}\text { P1 } \\
\text { Negative } \\
\text { Control } \\
\text { (mg/dl) }\end{array}$ & $\begin{array}{c}\text { P2 } \\
\text { Positive } \\
\text { Control } \\
\text { (mg/dl) }\end{array}$ & $\begin{array}{c}\text { Ethanol Extract of } \\
\text { the Squash1oo } \\
\text { mg/kgBB (mg/d) }\end{array}$ & $\begin{array}{c}\text { Ethanol Extract of } \\
\text { the Squash2oo } \\
\text { mg/kgBB (mg/d) }\end{array}$ \\
\hline U1 & 122 & 218 & 254 & 372 \\
U2 & 138 & 250 & 232 & 435 \\
\hline U3 & 116 & 303 & 267 & 398 \\
\hline U4 & 154 & 314 & 264 & 200 \\
\hline U5 & 140 & 309 & 375 & 438 \\
\hline U6 & 120 & 276 & 299 & 310 \\
\hline U7 & 126 & 377 & 360 & P3 \\
\hline
\end{tabular}

Description: U1 (Repeat 1), U2 (Repeat 2) U3 (Repeat 3), U4 (Repeat 4), U5 (Repeat 5) U6 (Repeat 6), U7 (Repeat 7).

Based on Table 2, it appeared that P1 group had KGD $<250 \mathrm{mg} / \mathrm{dl}$ while P2, P3 and P4 groups had KGD $\geq 250 \mathrm{mg} / \mathrm{dl}$. Since the data were normally distributed and the data variance was the same, Anova test (Table 3) was performed.

Table 3 showed that the KGD mean in the group $\mathrm{P} 1=129.67 \pm 14.50$; group $\mathrm{P} 2=$ $292.43 \pm$ 51.01; group $\mathrm{P}_{3}=314.0 \pm 49.97$, 
and group $\mathrm{P}_{4}=340.17 \pm 83.40$. The mean of KGD in group $\mathrm{P}_{2}, \mathrm{P}_{3}$, and $\mathrm{P}_{4} \geq 250$ indicated that this group had DM. Anova test results obtained $\mathrm{p}<0.001$, it meant there were differences statistically significant KGD mean in each group.

Table 3. Anova KGD test results after being induced with STZ $60 \mathrm{mg} / \mathrm{kgBW}$

\begin{tabular}{|c|c|c|c|c|c|c|}
\hline \multirow{3}{*}{ Group } & \multicolumn{5}{|c|}{ Blood Sugar I } & \multirow{3}{*}{$\mathbf{p}$} \\
\hline & \multirow{2}{*}{ Mean } & \multirow{2}{*}{ Median } & \multirow{2}{*}{ SD } & \multicolumn{2}{|c|}{ 95\% CI } & \\
\hline & & & & Low & Up & \\
\hline $\mathbf{P 1}$ & 129.67 & 124.00 & 14.50 & 114.45 & 144.88 & $<0.001$ \\
\hline P2 & 292.43 & 303.00 & 51.01 & 245.25 & 339.61 & \\
\hline P3 & 314.00 & 315.50 & 49.97 & 261.56 & 366.44 & \\
\hline$P_{4}$ & 340.17 & 347.50 & 83.40 & 252.64 & 427.69 & \\
\hline
\end{tabular}

Description: P1 is Negative control (mg/ dl), P2 is Positive control (mg/ dl), P3 is Ethanol extract Squash Fruit $100 \mathrm{mg}(\mathrm{mg} / \mathrm{dl}), \mathrm{P} 4$ is Ethanol Extract of SquashFruit $200 \mathrm{mg}(\mathrm{mg} / \mathrm{dl})$

An increase in KGD of the experimental animals $\geq 250 \mathrm{mg} / \mathrm{dl}$ was used as the basis of ethanol extract of the squash fruit in the treatment group. The dose of extract of ethanol extract of the squash fruit in the treatment group $\mathrm{P}_{3}$ was given $100 \mathrm{mg} /$
$\mathrm{kgBB}$ and in the treatment group $\mathrm{P}_{4}$ was given $200 \mathrm{mg} \mathrm{kg}$ per day. KGD measurements were done every 7 days ie day 7 , day 14, day 21 and $28^{\text {th }}$ day. The results of blood glucose measurements were shown in Table $5,6,7$, and 8 .

Table 4. Anova KGD test after giving ethanol extract of squash fruit in day $7^{\text {th }}$

\begin{tabular}{|c|c|c|c|c|c|}
\hline \multirow{3}{*}{ Group } & \multicolumn{4}{|c|}{ Blood Sugar II } & \multirow{3}{*}{$\mathbf{p}$} \\
\hline & \multirow{2}{*}{ Mean } & \multirow{2}{*}{ SD } & \multicolumn{2}{|c|}{ 95\% CI } & \\
\hline & & & Lower Limit & Upper Limit & \\
\hline $\mathbf{P 1}$ & 129.67 & 14.50 & 114.45 & 144.88 & $<0.001$ \\
\hline $\mathbf{P 2}$ & 274.71 & 53.42 & $225 \cdot 31$ & 324.12 & \\
\hline P3 & 207.67 & 34.82 & 171.13 & 244.21 & \\
\hline $\mathbf{P}_{4}$ & 209.50 & 23.98 & 184.33 & 234.67 & \\
\hline
\end{tabular}

Description: P1 Negative control (mg/ dl), P2 Positive control (mg/ dl), P3 ethanol extract of the squash $100 \mathrm{mg}(\mathrm{mg} / \mathrm{dl}), \mathrm{P} 4$ ethanol extract of the squash $200 \mathrm{mg}(\mathrm{mg} / \mathrm{dl})$

Based on the Anova test resulted in Table 4, it appeared that the KGD mean group $\mathrm{P} 1=$ $129.67 \pm 14.50$; group $\mathrm{P} 2=274.71 \pm 53.42$; group $\mathrm{P}_{3}=207.67 \pm 34.82$, whereas in the $\mathrm{P} 4$ group $=209.50 \pm 23.98$, there was a decrease of KGD in the treatment group while the negative control did not decrease at all and the positive control decreased. Based on Anova test results, it was obtained $\mathrm{p}<0.001$ which meant there was a statistically significant difference in KGD mean in each group.

Anova test results in Table 5 showed thatKGD mean happened in the $14^{\text {th }}$ day in group $\mathrm{P}_{1}=129.67 \pm 14.50$; group $\mathrm{P}_{2}=$ $274.71 \pm 53.42$; group $\mathrm{P}_{3}=170.83 \pm 25.31$, and group $\mathrm{P}_{4}=172.83 \pm 21.91$. There was a decrease of KGD mean in treatment group while in the control group there was no decrease of KGD mean. The $\mathrm{P}_{3}$ and $\mathrm{P}_{4}$ groups given the extract decreased KGD, while $\mathrm{P}_{1}$ and $\mathrm{P} 2$ did not decrease the KGD. Anova test results, obtained $\mathrm{p}<0.001$ which meant there was a difference of average KGD in each group and statistically significant. 
Table 5. Anova KGD test after giving ethanol extract of squash fruit in $14^{\text {th }}$ day

\begin{tabular}{ccccccc}
\hline & \multicolumn{5}{c}{ Blood Sugar III } & \multirow{2}{*}{ p } \\
\cline { 2 - 5 } Group & \multirow{2}{*}{ Mean } & \multirow{2}{*}{ Median } & \multirow{2}{*}{ SD } & \multicolumn{2}{c}{ 95\% CI } & \\
\cline { 5 - 6 } & & & & Lower Limit & Upper Limit & \\
\hline P1 & 129.67 & 124.00 & 14.50 & 114.45 & 144.88 & \\
P2 & 274.71 & 268.00 & 53.42 & 225.31 & 324.12 & \\
\hline P3 & 170.83 & 160.50 & 25.31 & 144.27 & 197.39 & \\
\hline P4 & 172.83 & 177.00 & 21.91 & 149.84 & 195.83 & \\
\hline
\end{tabular}

Description: P1 Negative control (mg/ dl), P2 Positive control (mg/ dl), P3 ethanolic extract of squash fruit $100 \mathrm{mg}(\mathrm{mg} / \mathrm{dl}), \mathrm{P} 4$ ethanol extract of squash fruit $200 \mathrm{mg}(\mathrm{mg} / \mathrm{dl})$

Table 6. Anova KGD test after giving ethanol extract of squash fruit in $\mathbf{2 1}^{\text {st }}$ day

\begin{tabular}{ccccccc}
\hline & \multicolumn{5}{c}{ Blood Sugar IV } & \multirow{2}{*}{ p } \\
\cline { 2 - 6 } Group & \multirow{2}{*}{ Mean } & \multirow{2}{*}{ Median } & \multirow{2}{*}{ SD } & \multicolumn{2}{c}{ 95\% CI } & \\
\cline { 3 - 6 } & & & & Lower Limit & Upper Limit & \\
\hline P1 & 129.67 & 124.00 & 14.50 & 114.45 & 144.88 & \\
P2 & 176.71 & 184.00 & 18.87 & 159.26 & 194.17 & \\
\hline P3 & 127.50 & 138.00 & 29.86 & 96.16 & 158.84 \\
\hline P4 & 125.17 & 128.50 & 18.10 & 106.17 & 144.17 & \\
\hline
\end{tabular}

Description: P1 Negative control (mg/ dl), P2 Positive control (mg/ dl), P3 ethanolic extract of squash fruit $100 \mathrm{mg}(\mathrm{mg} / \mathrm{dl}), \mathrm{P}_{4}$ ethanol extract of squash fruit $200 \mathrm{mg}(\mathrm{mg} / \mathrm{dl})$

Based on the Anova testresults in table 6, it showed the mean of KGD in group $\mathrm{P} 1=$ $129.67 \pm 14.50$, group $\mathrm{P} 2=$ average $176.71 \pm$ 18.87, group $\mathrm{P}_{3}=$ mean $127.50 \pm 29.86$, while KGD group $\mathrm{P}_{4}=125.17 \pm 18.10$ average. KGD increased in the mean decrease in KGD occured in groups $\mathrm{P}_{2}, \mathrm{P}_{3}$,

Table 7. Anova KGD test after giving ethanol extract of squash fruit in $28^{\text {th }}$ day

\begin{tabular}{ccccccc}
\hline & \multicolumn{5}{c}{ Blood Sugar V } & \multirow{2}{*}{ p } \\
\cline { 2 - 5 } Group & \multirow{2}{*}{ Mean } & Median & SD & \multicolumn{2}{c}{ 95\% CI } & \\
\cline { 5 - 6 } & & & & Lower Limit & Upper Limit & \\
\hline P1 & 127.67 & 128.50 & 12.925 & 114.10 & 141.23 & \\
P2 & 184.29 & 186.00 & 21.242 & 164.64 & 203.93 & \\
\hline P3 & 145.33 & 145.50 & 11.130 & 133.65 & 157.01 \\
\hline P4 & 133.50 & 130.00 & 38.188 & 93.42 & 173.58 & \\
\hline
\end{tabular}

Description: P1 Negative control (mg/ dl), P2 Positive control (mg/ dl), P3 ethanolic extract of squash fruit $100 \mathrm{mg}(\mathrm{mg} / \mathrm{dl}), \mathrm{P} 4$ ethanol extract of squash fruit $200 \mathrm{mg}(\mathrm{mg} / \mathrm{dl})$

Based on Table 7 above, it could be seen that the mean of KGD on day 28 in group $\mathrm{P} 1=129.67 \pm 12.92$, group $\mathrm{P} 2$ average $=$ $184.29 \pm 21.24$, group $P_{3}$ average $=145.33$ \pm 11.13 , group $\mathrm{P}_{4}=133.50 \pm 38.19$ was lower when compared to mean on $\mathrm{P} 2$, and and $\mathrm{P} 4$, whereas in group $\mathrm{P} 1$ there was no decrease in KGD. In the Anova test, the value of $\mathrm{P}=0.000$ meant that there was significant difference ( $\alpha$ 5\%, p <0,05), it could be concluded that there was difference of KGD mean in each group. 
The result showed that there was improvement of pancreatic organ of male white mouse (Mus musculus L), DD
Webster strain in group $\mathrm{P}_{3}$ and $\mathrm{P}_{4}$, while in $\mathrm{P} 2$ the pancreas diameter decreased, as seen in Picture 1.

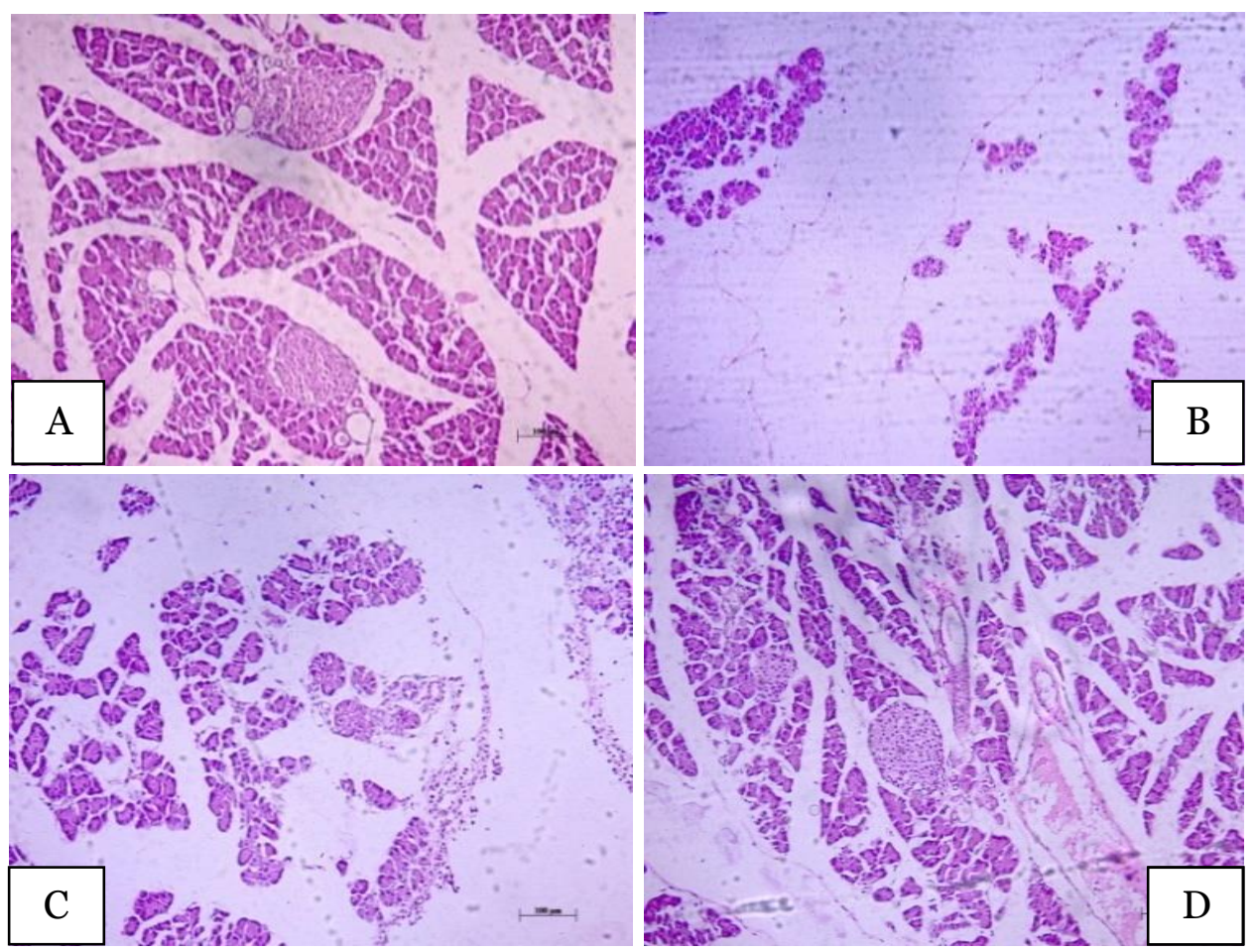

Picture 1. Histopathology of pancreatic $\beta$-cell diameter

Description: A. P1 (negative control) had a pancreatic $\beta$ cell diameter of $238.7 \mu$ m indicating that normal pancreatic $\beta$ cell diameter $(100-400 \mu \mathrm{m})$. B. Group P2 (positive control) showed diminished pancreatic $\beta$ cells indicating pancreatic $\beta$ cells damaged by the induction of Streptozotocin with a small size of $68.79 \mu \mathrm{m}$. C. The $\mathrm{P}_{3}$ group showed that the pancreatic diameter of p-cell size was improved, measuring $93.11 \mu \mathrm{m}$. D. P4 group showed that normal pancreatic $\beta$ cell size, with pancreatic $\beta$-cell diameter size was $182.69 \mu \mathrm{m}$.

Picture 1. Showed that the pancreas diameter backed to normal in the $\mathrm{P}_{4}$ treatment group while in the $\mathrm{P}_{3}$ treatment group did not return to normal but an increase in diameter when compared with positive control P2.

\section{DISCUSSION}

Male white mice can be induced into DM with STZ, this mechanism is mediated primarily by the formation of ROS-free radicals, RNs that cause destruction of pancreatic $\beta$ cells (Srinivasan and Ramarao, 2007). There were significant differences in blood sugar levels between groups, where significant decreases occurred in the group given ethanol extract of squash fruit 100 $\mathrm{mg} / \mathrm{kgBB}$ and $200 \mathrm{mg} / \mathrm{kgBW}$. The group receiving the $200 \mathrm{mg}$ dose experienced the lowest decrease of KGD, this result was similar to Maity et al., 2013. The decrease of KGD in the treatment group was due to the giving of the ethanol extract of the flasks containing flavanoid (Siciliano et al., 2004; Marliana et al. , 2005). Flavonoids are antidiabetes by interfering with glucose uptake in the intestine, improving glucose 
tolerance, disturbing carbohydrate metabolism through inhibition of enzyme $a$ amylase and enzyme a glucosidase, stimulating glucose uptake in peripheral tissues besides flavonoids also stimulating insulin secretagogues and act like stimulating insulin synthesis of glycogen (insulin mimetics) (Brahmachari, 2011; Piparo, 2008; Getha, et al., 2010).

The decrease in KGD in P2 group may occur due to self-healing mechanisms by the body through repair of pancreatic $\beta$ cells and new cell division (mitosis) that occur gradually. A decrease in the number of pancreatic $\beta$ cells in hyperglycemic animals began to appear on day 7 and continued to decline until the 28th day (Erwin et al., 2012). The decrease of KGD in $\mathrm{P}_{3}$ and $\mathrm{P}_{4}$ groups had begun to be seen after administration of ethanol extract of squash fruit on the 7 th day and returned nomal on day 28. This situation indicates that in $\mathrm{P}_{3}$ and $\mathrm{P}_{4}$ the decrease of KGD due to flavornoid effect contained in ethanol extract of peanut pump while in group $\mathrm{P}_{2}$ decrease of KGD start happening on 21st day caused by repair mechanism of pancreatic $\beta$ cells indicated by improvement of KGD mouse .

The results showed that the pancreatic $\beta$ cell diameter was different in treatment group $\mathrm{P}_{3}$ and $\mathrm{P}_{4}$, due to flavonoids in ethanol extract of Pumpkin Siam (S.edule Jacq Swartz) and actlike an antioxidant by repairing damage of pancreatic tissue due to DNA alkylation by STZ so that secretion increased insulin and decreased blood glucose levels (Suryani et al., 2013).

Based on the results and discussion of the study, it can be concluded that the ethanol extract of the squash fruit $200 \mathrm{mg} /$ kgBB can significantly decrease the blood sugar level of mice, there is difference of pancreatic $\beta$ cell diameter group given ethanol extract of squash fruit $200 \mathrm{mg} /$ $\mathrm{kgBB}$ compared to ethanol extract group of squash fruit $100 \mathrm{mg} / \mathrm{kgBB}$ and control group.

\section{REFERENCE}

Akbarzadeh AD, Norouzian MR, Mehrabi Sh, Jamshidi,Farhangi, Verdi AA, Mofidian SMA, Rad BL (2007). Induction Of DM By Streptozotocin In Rats. Indian Journal of Clinical Biochemistry. 22 (2): 60-64.

Atalay M, Laaksonen DE (2002). DM, oxidative stress and physical exercise. Journal of Sports Science and Medicine. 1: 1-14.

Brahmachari, Goutam (2011). Bioflavonoids with promising anti-diabetic potentials: A critical survey. Study signpost, 6619370:187-212.

Erwin, Etriwati, Rusli (2012). Mencit (Mus musculus) galur balb-c yang diinduk-sikan streptozotosin berulang sebagai hewan model DM. Jurnal Kedokteran Hewan 6(1).

Gethaa, Sahgal, Ramanathan S (2010). Brine Shrimp Lethality and Acute Oral Toxicity Studies on Swetwnia Mahagoni (Lin) Jacq. Seed Methanolic Extract. Pharmacognosy Study. 2(4): 215-220.

Moussa SA (2008). Oxidative stress in dia-betes mellitus. Rom J Biophys 18(3): 225-36.

Nugroho AE (2006). Animal models of diabetes mellitus: Pathology and mechanism of some diabetogenics. Biodiversitas, J Biol Divers 7(4):378-82.

Park, Han MH, Ji Sook (2012). Hypoglycemic Effect of Padina arborescens Extract in Streptozotocininduced Diabetic Mice, Prev Nutr Food Sci. 17: 239 - 244. 
Raza, Haider, John A (2012). Streptozotocin-Induced Cytotoxicity, Oxidative Stress and Mitochondrial Dysfunction in Human Hepatoma HepG2 Cells. Int. J. Mol. Sci. 13, 5751-5767; doi:10. 3390/ijms 13055751.

Redha A (2010). Flavonoid: Struktur, Sifat Antioksidatif Dan Peranannya dalam Sistem Biologis. Jurnal Belian. 9(2).

Ridwan A, Astrian RT, Barlian A (2012). Pengukuran Efek Antidiabetes Polifenol (Polyphenon 60) Berdasarkan Kadar Glukosa Darah dan Histologi Pankreas Mencit (Mus musculus L.) S.W. Jantan yang Dikondisikan DM. Jurnal Matematika \& Sains. 17(2).

Robertson RP, Harmon JS (2007). Pancreatic islet $\beta$-cell and oxidative stress: The importance of glutathione peroxi-dase. FEBS Lett 581(19): 3743-8.

Rohyami Y (2008). Penentuan Kandungan Flavonoid dari Ekstrak Metanol Daging Buah Mahkota Dewa (phaleria macrocarpa Scheff Boerl). Logika. 5(1).

Maity S, Firdous SM, Debnath R (2013). Evaluation of antidiabetic activity of ethanolic extract of Sechium edule fruits in alloxan-induced diabetic rats. World J Pharm Pharm Sci 2(5): 361221.

Marliana SD, Suryanti V (2005). Skrining fitokimia dan analisis kromatografi lapis tipis komponen kimia buah labu siam (Sechium edule Jacq.Swartz.) dalam Ekstrak Etanol. Biofarmasi 3(1):26-31.

Setiawan B, Suhartono E. (2005). Stres Oksidatif dan Peran Antioksidan pada DM. Majalah Kedokteran
Indonesia. 55(2). Available from http://mki.idionline.org/index.php? uPage=mki.mki_dl\&smod=mki\&sp $=$ public\&key=MTItMTQ.

Suryani N, Tinny EH, Aulanni'am (2013). Pengaruh Ekstrak Metanol Biji Mahoni terhadp Peningkatn Kadr Insulin, Penurunan Ekspresi TNF- $\alpha$ dan Perbaikan Jaringan Pankreas Tikus DM. Jurnal Kedokteran Brawijaya. 27(3)

Piparo Elo, Scheib H, Frei N, Williamson G, Grigorov M, Chou CJ (2008). Flavo-noids for controlling starch digestion: structural requirements for inhibiting human r-amylase 3555-61.

Shradha B, Sisodia SS (2010). DM, Dyslipidemia, Antioxidant And Status Of Oxidative Stress. International Journal of Study in Ayurveda \& Pharmacy, 1(1).

Sheikhpour R (2013). Diabetes and oxidative stress : The mechanism and action. Iran $\mathrm{J}$ diabtes Obes 5(1).

Siciliano T, De Tommasi N, Morelli I, Braca A (2004). Study of flavonoids of Sechium edule (Jacq) Swartz (Curcubitaceae) different edible organs by liquid chromatography photodiode array mass spectrometry. Journal of Agricultural and Food Chemistry: 6510-6515.

Srinivasan K, Ramarao P (2007). Animal models in type 2 diabetes study: an overview. Indian J Med Res 125(3): 451-72.

SuarsanaIN, Priosoeryanto BP, Bintang M, Wresdiyati T (2010). Profil Glukosa Darah dan Ultrastruktur Sel B Pankreas Tikus yangDiinduksi Senyawa Aloksan. JITV, 15(2): 118123. 